\title{
Latin American Economic History, Business History and Economics of Enterprise: Current trends
}

\begin{abstract}
Recent studies about Latin American business are worried about their position on the emerging and global economies. In this article we want to remark the important role of the universities, institutes, schools, and research centers in Latin America that make possible the research work and the publication of Bulletins, Journals and books on business history. In this way, we observe the recent activities of associations and international groups that focus in Latin American Business History in the last twenty five years. We identify the advances and goals in this arena and agreed with Carlos Davila about the thematic diversity and the need to achieve methodological rigor and theoretical propositions. For this reason, we emphasize the historical role of Latin American enterprises and the role of the family business, and their position in the global economies. This article has a double aim, on the one hand, we offer an overview and a state of the art about Latin American Business History. And, on the other hand, we emphasize, within the field of Latin American business, emergent studies that show the potential of this discipline to participate in broader debates about innovation, corporate governance and learning.
\end{abstract}

Keywords: Latin American Business History; Emerging Economies; Family Business; Corporate Governance; Innovation and Learning

Corresponding author. E-mail: almaraz@ colef.mx

Received 30 October 2015 - Accepted 30 December 2015

This is an Open Access article distributed under the terms of the Creative Commons Attribution-Non-Commercial-No Derivatives License (http://creativecommons.org/licenses/by-nc-nd/4.0/), which permits non-comercial re-use and distribution, provided the original work is properly cited, and is not altered or transformed in any way. 
Studies on Latin American Economic History and Economy of Enterprises are related to entrepreneurial history and organizations, respectively. Different efforts have been launched from different economic history associations, all of them constituted formally in the last twenty-five years by the Asociación de Historia Económica del Norte de México (1992), Asociación Uruguaya de Historia Económica (1992), Asociación Argentina de Historia Económica (1997), Asociación Mexicana de Historia Económica (1998), Grupo Iberoamericano de Estudios Empresariales e Historia Económica (2006) -unique in its scope because of the permanent participation of researchers from Argentina, Colombia, México, Perú and Spain-, the Asociación Colombiana de Historia Económica (2007), Asociación Chilena de Historia Económica (2008), Associação Brasileira de Pesquisadores em História Econômica (2009), Asociación de Historia Económica del Caribe (2010), and Asociación Peruana de Historia Económica (2011). These groups have organized national and international conferences like the Annual Latin American Economic History Conference and the Annual Economic History Workshop from AMHE where most experts on Latin American economic history participate. Also an important role has been played by universities, institutes, schools, and research centers, that make possible researching work and publishing of Bulletins.

Bulletins and specialized Journals have been the main diffusion framework of debates on economic history in Latin America and evolution of businesses. Before 1980, the participations were rarely published in international Journals like The Business History Review edited by Cambridge University since $1953^{1}$; The Family Business Review edited since 1988 (Lansberg and Perrow 1991, 127-147) and the Revista de Investigaciones de Historia

\footnotetext{
${ }^{1}$ Started in 1926 as Bulletin of the Business Historical Society.
} 
Económica edited by the Asociación Española de Historia Económica, which started to be published in its current online format in 2005. Since 1983, a new space was opened in the Revista de Historia Económica - Journal of Iberian and Latin American Economic from Cambridge University published every trimester. Other spaces were being added to these platforms headed by different associations on economic history (Table 1). Other journals and reviews close to economic history which have allowed the publication of studies on Latin American entrepreneurial development have been: Historia Mexicana (Mexican History), El Colegio de México, Revista de Investigación Económica (Economic Research Review), UNAM; Historelo Colombian Local and Regional History Review; Desarrollo Económico (Economic Development) -an electronic review in collaboration with Jstor-; Estudios Gerenciales (Management Studies) by Elsevier, Revista Económica del Caribe (Caribbean Economic Review), Universia Business Review, Trimestre Económico (Economic Trimestral), Fondo de Cultura Económica, Revista Innovar (Innovation Review) in Argentina, and Apuntes Social Sciences Review in Perú, among others.

The publishing of books related to economic and business history has been conducted with regularity in Colombia, Argentina, Brazil and Mexico for the last two decades. This period coincides with the launching of most Latin American associations on economic history. In this way, the academic debates incorporated data and thought about big business in globalization, the conformation of local elites, and the regional productive models. In these countries, since 1970, research work on entrepreneurial history related to businesses and some economic sectors, from the $19^{\text {th }}$ century to the 21 rst century, has been very much active (Derossi 1977; Cerutti 1992; Szmrecsányi and Maranhao 1996; Cerutti and Marichal 1997; Basave 2000; Basave 2001). 
Table 1. Economic History Journals and Bulletins in Latin America

\begin{tabular}{|c|c|c|c|}
\hline Name / year & Type & Country & Institution \\
\hline $\begin{array}{l}\text { História Econômica \& História de } \\
\text { Empresas (Economic History \& } \\
\text { Enterprises History [1993] }\end{array}$ & Printed & Brazil & $\begin{array}{l}\text { Brazilian Association } \\
\text { Economic History }\end{array}$ \\
\hline $\begin{array}{l}\text { América Latina en la Historia } \\
\text { económica (Latin America in the } \\
\text { Economic History) }[1994 / 2004]^{3}\end{array}$ & Electronic & Mexico & José Maria Mora Institute \\
\hline $\begin{array}{l}\text { Boletín de la Cátedra Corona } \\
\text { (Corona Chair) }[2001]^{4}\end{array}$ & $\begin{array}{c}\text { Printed / } \\
\text { Electronic }\end{array}$ & Colombia & $\begin{array}{c}\text { Management Faculty of Los } \\
\text { Andes University }\end{array}$ \\
\hline $\begin{array}{c}\text { Bulletin of Mexican Economic } \\
\text { History }[2001]^{5}\end{array}$ & Electronic & Mexico & $\begin{array}{l}\text { Mexican Association of } \\
\text { Economic History }\end{array}$ \\
\hline $\begin{array}{c}\text { Uruguayan Economic History } \\
\text { Review }[2002 / 2011]^{6}\end{array}$ & Printed & Uruguay & $\begin{array}{l}\text { Uruguayan Economic } \\
\text { History Association }\end{array}$ \\
\hline $\begin{array}{l}\text { Anuario CEED } \\
\text { (Yearbook of the Center of } \\
\text { Business and Development } \\
\text { Economic Studies) [2007] }\end{array}$ & Printed & Argentina & $\begin{array}{l}\text { Economic Research Institute } \\
\text { of Buenos Aires University }\end{array}$ \\
\hline H-industri@ [2007] & Electronic & Argentina & Buenos Aires University \\
\hline Time \& Economy $[2014]^{9}$ & Electronic & Colombia & $\begin{array}{c}\text { Jorge Tadeo Lozano } \\
\text { University }\end{array}$ \\
\hline
\end{tabular}

Source: Own elaboration based on public information.

\footnotetext{
${ }^{2}$ Published every six months.

${ }^{3}$ Between 1994-2004 the title was Boletín de Fuentes. Published every three year since 2004.

${ }^{4}$ Published every six months.

${ }^{5}$ Published every four months.

${ }^{6}$ Between 2002-2010 the title was Boletín de Historia Económica de AUDHE. Since 2013 published every two years.

${ }^{7}$ Published every year.

${ }^{8}$ Published every six months.

${ }^{9}$ Published every six months.
} 
Thematic diversity requires methodological rigor and theoretical propositions (Dávila et al. 2013). This is why we want to remark two discussions about Latin American businesses: a) the role of enterprises and the role of family businesses, and b) their position in the global economies, as developed in the lines below.

In contrast to the discussions in the United States where one of the main issues is on corporate governance and the family in small and medium size businesses,${ }^{10}$ for the Latin American historians it is very important to understand: the adaptation and internationalization processes of businesses in specific productive sectors, as well as to analyze how the family has gained presence in the endurance of entrepreneurial networks (Kosacoff and Ramos 2010, 56-75), in the technological change processes, and the managerial alternative routes -contrasting with Chandler's managerial theory-. However, it is necessary to expand the dialogue among Latin American and North American, Asian, and European communities of scholars, about innovation, technological change, and learning in family business and business evolution in Latin America.

The recent discussions about business perdurability and the participation of family business in different spheres of Latin American economies deserve theoretical, methodological and empirical comparative reflections (Lansberg and Perrow 1991; Poza 1995, 301-211; Morlán 2007, 13-38; Fernández 2012, 96; Miller 2010a, 90; Barbero 2014, 95), which will allow discussion about the accomplishments of Latin American enterprises in globalization. Specialists in economic history, like Erro, Amatori and Jones, warn us about how the challenges of this discipline face this era of globalization (Erro 2003; Amatori and Jones

\footnotetext{
${ }^{10}$ According to Muntean: «Although family controlled firms permeate finance, economics, and politics in the United States, they are infrequently studied by leading economists and organizational theorists, who assume an ideal type ... with complete separation of ownership from management». (Muntean 2008, 4).
} 
2003). Debates about learning, organizational development and the continuity of business networks will be added to issues such as Latin American bank development and big enterprises -widely studied until the 1990s (Marichal and Cerutti 1997; Peres 1998; Cerutti 2006)-. The recent positioning of multinational businesses, from -so called- emerging economies, deserves to be analyzed in depth as pointed out by Ma. Inés Barbero a few decades ago (Barbero 2014; Barbero 2003; Miller 2010a).

The most of native Latin American businesses before 1850 corresponded to colonial productive models (1542-1810). Once the independence movements expanded in Latin America along early $19^{\text {th }}$ century, new forms of mercantile and productive associations were defined as part as modern business history (Tortolero 1996). Parallel to formal business registrations regulated by the Commerce Codes in different countries, new business registration appeared. The registration acts show us different kind of shareholders: foreigners with foreign residence, foreigners with local residence, and often Mexicans by naturalization. After a few decades we can found the first descendants of first businessmen generation

The combination of all these groups gave way to the emergence of local elites and to different forms of establishing businesses and strategies for accumulation (Cerutti 2000, 3-27; Cerutti 2002, 262). In the last century and a half, in Latin America, we find a high entrepreneurial diversity which later will be discussed more consistently, especially when dealing with the evolution of Latin American businesses recently positioned in international competitive markets, and with the validity of the family observed in the corporate governance of firms (Casanova 2015; Cerutti 2015, 71-94 and 153-187; Lane et al. 2010, 155-169). Mainly economic historians from Argentina, Colombia and Mexico are heading Latin American debates on these aspects (Barbero 2008; Fernández 2010, 147-167; Barbero and Lluch 2014; 
Almaraz 2007a, 113-142; Almaraz 2007b; Bueno et al. 1979, 39-92; Cerutti 2005; Gilbert 2009, 43-72). Nevertheless, the consolidation of a mainstream scholarship about Latin American businesses is still under construction. Rory R. Miller emphasized that: «On the one hand, case studies of individual firms have proliferated during the last two decades, especially in Mexico, Argentina, and Colombia, as a new generation of researchers has entered the field... Yet, on the other hand, studies of Latin American business have not yet entered the disciplinary mainstream» (Miller 2010b, 637-674).

\section{Family Business and Entrepreneurial Families}

In recent revisions of family business literature in Latin America, we can observe some studies conducted in the 1970s -1980s, where the perspective has been anthropological and regional, as in the case of Mexico. In this perspective, we can highlight the work of Luis Alfonso Ramirez who has studied entrepreneurial families of Lebanese origin in the Yucatan peninsula. ${ }^{11}$ Meanwhile, Gamboa had made the role of families in the business from an historic perspective visible (Gamboa 1986, 57-81). The works of Lizama and Valerio have also applied a sociohistorical perspective (Valerio 2002; Lizama 2000), and recently the research of González and Almaraz has been integrated, focusing specifically on the Northwest region of Mexico (González 2001, 13-28; Almaraz 2007a, 113-142; Almaraz 2007b; Almaraz 2010, 87-122). Nonetheless, the great advancement in family and enterprise studies has been conducted by Cerutti, who is one of the main historians on economic history and business

\footnotetext{
${ }^{11}$ Mexican anthropologists rarely incorporated economic issues. Between the 1970s and 1980s some works related to business and family were published: (Bueno et al. 1979, 39-92; Icazuriaga 1979; Von Mentz et al. 1988; Lomnitz and Pérez Lizaur 2001, 1993, 1979).
} 
development in Mexico. In his review on business research in the North of Mexico he mentions:

«[Since 1990 highlight] the research on family business, individuals, and CEO in economic activities studies [which explains...] the explicit intention to investigate and verify the trajectory of regional bourgeoisie, whose existence and eventual significance had been literally denied by a historiography saturated by anti-entrepreneurial prejudice and very dependent of the national and centralist view of the socioeconomic processes», (Cerutti 2007, 122).

In other Latin American countries, the studies related to family business have been focused on the development of economic sectors. Nevertheless, the contributions in the last decades have been of great importance, which puts us on the threshold of corporate history and a much clear definition of our subject of study, as noted by Dávila $(2007,39-70)$. We are observing a growing discussion about the definition of family business and some enquiries about its continued existence, the specialization of family business versus the diversification over time, and its presence in the corporate governance. A related topic is the conceptualization of entrepreneurial families or family entrepreneurs. The research work developed until now allows us to infer about some aspects of organizations like the strong family foundations, and the new institutional, mercantile and technological environments. Therefore, we can refer to the work of Josep Tapies et al. (2014) who revealed how the family based enterprise organizes and subsists with generational changes, acquiring a relevant positioning. In this same line, Fernández has presented in recent years the topic of family property at the center of the current entrepreneurial and businesses discussion (Fernández 2010; 2015). We must be reading other works related to family business focused on technology and management of 
family to contrast the pathways of Latin American businesses (Del Giudice et al. 2011; Hougaz 2015).

\section{The Economics of Enterprise in Latin America}

A revision of literature related to the Economics of the Enterprise in Latin America allows us to identify the main trends and favorite thematic areas developed by the scientific community. To identify these areas, for the past four years, we have analyzed scientific articles published in international reference magazines. The first thematic approach to these articles, whose typology has been determined by a quantitative analysis of the scientific production in this field of work, suggests a general classification into two criteria easily identified: the research referring to Innovation and Entrepreneurship, and the rest of the work to be classified under a diversity of areas which include the economics of business, with special attention to the Latin American case in areas related to Information Technologies and Communications, Corporate Social Responsibility, entrepreneurial financing, and general management.

In relationship to the related research on Innovation and Entrepreneurship, we have authors like Amorós, Fernández and Tapia (2012, 249-270); Chaston and Scott (2012, 1161-1177); Lederman et al. (2014); Castellacci (2015, 43-58); o Crespi (2012, 273-290); who have performed a regional analysis on the variables that boost innovation in Latin America.

There are common aspects in the perspective of these investigations. First, the authors assume innovation as an analytical valid variable, and endogenous to the entrepreneurial development. After considering this assumption, there is the tendency to confirm the existence of a minimum innovative dynamic in the region because they claim there are no conditions for its promotion and development, neither from an institutional macro perspective (politics), nor from a micro point of view (management-corporate culture). In this sense, for 
example, the title of Lederman's et al. (2014) is paradigmatic: «Latin American Entrepreneurs: Many Firms But Little Innovation». Regularly, researchers try to identify the variables that may promote innovation processes in emerging economies by using the Latin American ones as a case study. In most of the cases, corporate culture is defined with those aspects related to training and qualification, generation of technology and applied knowledge, and to incentives, as well as to the most important causes of its technological gap. In the same way, we observe a certain proliferation of literature, which incorporates the sectorial analysis and case study approach for different countries in the region with a clear preference for Colombia, Mexico and Brazil. In this segment, the work by and Páez (1998, 91-90); Vizcarra, López Torres and Yánez Ruiz (2013, 55-66); Araneda-Guirriman, Pedraja-Rejas and Rodríguez Ponce (2015); and Santos, Basso, Kimura and Kayo (2014, 527-535) are considered to be paradigmatic and paradoxical.

In relationship to different publications, we appreciate that international journals -those which have included this research in their table of contents- tend to set a thematic profile but not a preconceived preference for the region. When studies on Latin America are published, they are set as case studies within a concrete methodological analysis. Therefore, journals like Management Decision, Journal of Business Research, International Entrepreneurship and Management Journal do not center their interest in investigating about the becoming and procedures of Latin American economies and businesses. We think that this is an important variable to consider at the moment of positioning the journal, since we are sure there is a tendency to understand the corporate behavior and evolution from a perspective that works in a concrete and specific manner in Latin America. Nevertheless, the most likely publications to promote development of this type of research with a genuine undertone of interest for Latin 
American businesses issues are linked to universities and research centers in different cities within the region, as Revista EAN, Revista Global de Negocios, la MPRA, Revista Virtual Universidad Católica del Norte, la Revista Idesia, or supranational organisms of analysis like the Comisión Económica para América Latina y el Caribe (CEPAL), The World Bank or the World Development.

Regarding the literature identified as belonging to the field of Economics of Enterprises, we have confirmed a considerable production of work related to ICTs, Corporate Social Responsibility, business financing, and general management. We consider that the concern researchers have is correlated to the classic challenges of regional economy, as testified by a contextualized document about the minimum common denominator of the corporate, political and social reality in Latin America. The research by Botello Peñaloza et al. (2015, 3-15); Quinones, Nicholson and Heeks (2015, 179-208), may be examples that illustrate the growing preoccupation about the impact of new technologies in the performance of Latin American businesses.

Within the work related to management, the concern for Corporate Social Responsibility and management mechanisms of control is much present; the work of Penfold, Oneto and Rodríguez Guzmán (2015); Wendlandt, Valdés, Martínez and Ochoa (2015); Bae et al. (2012, 412-435); Cardona (2014); McCarthy, et al. (2012, 27-38); and Garay and Font (2013, 3846) address their interest to the influence of internal management processes as well as to the elements that coincide with the social impact of the business and its environment. The heterogeneity in the approach of this type of research tends to fall mainly in a study case methodology, centered on the size of the corporation in an endogenous variable that conditions it, or in a concrete geographic area. As we have observed in the work related to 
entrepreneurship and innovation, highly qualified international journals tend to show a clear thematic profile, but not a pre-established preference for the Latin American region. When studies are referred on Latin America surface, they are considered as study cases within a concrete methodological analysis. In this regard, we have identified the Journal of Financial Economics, Journal of Business Ethics, Tourism Management Perspectives, Emerging Markets Review. As well as in the previous case, the publications which are more inclined to foster development of this type of research focusing in Latin America tend to be related to universities or research centers in different places of the region. Some titles are Revista de Estudios Gerenciales, Cuadernos de Administración (Universidad del Valle) o los Cuadernos de Economía. Other works related to Enterprise Economics in Latin America as an axis of scientific interest have been related to business financing. The research of Servina, Lensinkb and Van den Berg (2012, 2136-2144); and Maquieira, Preve and Sarria-Allende (2013, 118148); may be of great information. The Journal of Banking \& Finance, Emerging Markets Review are two of the journals that see Latin America as a laboratory where they can test theories related to difficulties in financing that corporations may find in emerging economies. Once more, we find articles that address research towards an analysis related to the environment and consider the region as the main object of study: Ibáñez et al. (2015).

In recent years, Latin America has also been the object of study, and an abundance in the production of research related to entrepreneurial governance has been observed: Carmen Briano Turrenta and Saavedra García (2015, 275-286); Jardon and Martos (2012, 462-481); Blancoa and Golik $(2015,1865-1888)$. At the same time there is a growing number of studies about the impact of globalization in the performance of Latin American corporations: Botello (2014); Staats and Biglaiser (2012, 193-202); and Iacovone, Rauch \& Winters (2013). 


\section{Final remarks}

Latin American studies can offer excellent platforms for discussions about global debates around innovation, knowledge, family businesses, technological adaptation and change, and issues related to internationalization processes. All of them are methodologically relevant as case of study. And we need to construct a solid theoretical framework to understand origins, transitions and adaptation processes. The recent position of Latin American businesses in global markets must be analyzed in a much broader debate. ${ }^{61}$ In Latin American contexts there seems to be a clear correspondence between the discussions about family adaptation patterns and the entrepreneurial continuity, but there are a lack of discussions about industrialization and technological development of the corporations and big family business in those emerging economies. As regards the research on the Economics of the Enterprise, we observe that international journals tend to accept works where Latin American enterprises are conceived as study cases of BRICS; and when the focus is on the study of firm behavior from the Latin American perspective, the publications commonly refer to regional analysis or to descriptions of international organizations.

The dialogue among different groups of specialists about entrepreneurial history and Latin American entrepreneurial development cannot be postponed if we want to understand the different business evolution processes and new entrepreneurial networks.

\section{REFERENCES}

Almaraz Alvarado, Araceli. 2007a. "El boom de las empresas extranjeras en el Valle de Mexicali y sus efectos en las relaciones empresariales locales (1912-1930).” Frontera Norte XIX, 37:113-142. Almaraz Alvarado, Araceli. 2007b. Origen y continuidad de los empresarios de Mexicali, Baja California (1912- 1939). PhD diss., CIESAS-Guadalajara. 
Almaraz Alvarado, Araceli. 2010. "La configuración del tejido empresarial en el noroeste de Baja California: empresarios y sociedades mercantiles en Mexicali y su valle de 1874 a 1939.” In Relaciones Productivas y Finanzas en el Norte de México, S. XIX-XX, edited by Araceli Almaraz and Moisés Gámez, 87-122. Tijuana: El Colegio de la Frontera Norte.

Amatori, Franco and Geoffrey Jones, eds. 2003. Business History around the World. Cambridge: Cambridge Press.

Amorós, José Ernesto, Cristóbal Fernández, and Juan Tapia. 2012. "Quantifying the relationship between entrepreneurship and competitiveness development stages in Latin America." International Entrepreneurship and Management Journal 8(3):249-270.

Araneda-Guirriman, Carmen, Liliana Pedraja-Rejas, and Emilio Rodríguez Ponce. 2015. "Innovación en las regiones de Chile: una aproximación desde el análisis de sus empresas." Idesia 33, 1, Arica.

Bae, Kee-Hong, Jae-Seung Baek, Jun-Koo Kang, and Wei-Lin Liu. 2012. "Do controlling shareholders' expropriation incentives imply a link between corporate governance and firm value? Theory and evidence." Journal of Financial Economics 105(2):412-435.

Barbero, María Inés. 2003. "Business History in Latin America. Issues and Debats." In Business History Around the world, edited by Amatori and Jones: 317-338. Cambridge: Cambridge University Press.

Barbero, Maria Inés. 2008. "Business History in Latin America: A Historiographical Perspective." Business History Review 82:555-575.

Barbero, María Inés. 2014. Multinacionales latinoamericanas en perspectiva comparada. Bogotá: Universidad de los Andes-Facultad de Administración, Cátedra Corona 23.

Barbero María Inés and Andrea Lluch. 2014. "El capitalismo familiar en Argentina: modelos y dinámicas en el largo plazo.” Paper presented at the VII Coloquio del Grupo Iberoamericano de Historia Económica y Estudios Empresariales, Tijuana, November. 
Basave, Jorge. 2000. Empresas mexicanas ante la globalización. México: Instituto de Investigaciones Económicas de la Universidad Nacional Autónoma de México.

Basave, Jorge. 2001. Un siglo de grupos empresariales en México, Textos breves de economía. México: Instituto de Investigaciones Económicas-UNAM/Grupo Editorial Miguel Ángel Porrúa.

Blancoa, María Rita, and Mariela Natacha Golik. 2015. "Born under a lucky star? Latin American CEOs' perceptions about their own career development." The International Journal of Human Resource Management 26(14):1865-1888

Botello Peñaloza, Alberto, Aura Cecilia Pedraza Avella, and Orlando Enrique Contreras Pacheco. 2015. “Análisis empresarial de la influencia de las TIC en el desempeño de las empresas de servicios en Colombia." Revista Virtual Universidad Católica del Norte 45:315http://revistavirtual.ucn.edu.co/index.php/RevistaUCN/article/view/652

Botello, Héctor Alberto. 2014. "Condiciones y determinantes de la internacionalización de las empresas industriales latinoamericanas." Revista Apuntes 41.

Briano Turrenta, Guadalupe del Carmen, and María Luisa Saavedra García. 2015. "La composición del consejo de administración y la estructura accionaria como factores explicativos de la transparencia en el gobierno corporativo en Latinoamérica: evidencia en empresas cotizadas de Argentina, Brasil, Chile y México.” Estudios Gerenciales 31(136):275-286.

Bueno, Carmen et al. 1979. "Empresarios norteamericanos en el México actual.” In Simposio sobre empresarios en México. Empresarios mexicanos y norteamericanos, y la penetración de capital extranjero (siglo XX), Marisol Pérez, Carmen Bueno, Kathy Denman, Carmen Icazuriaga y José de Jesús Martínez, 39-92. México: Centro de Investigaciones Superiores del INAH (Cuadernos de la Casa Chata), 23, III.

Cardona Vélez, Germán Horacio. 2014. "Analysis of the impact of changes made in the corporative control of company value in Latin America." Cuadernos de Economía 33(62). 
Castellacci, Fulvio. 2015. "Institutional Voids or Organizational Resilience? Business Groups, Innovation, and Market Development." Latin America. World Development 70:43-58.

Casanova, Lourdes. 2015. "Las multinacionales latinoamericanas ante la nueva realidad." In Familias empresarias y grandes empresas familiares en América Latina y España: Una visión de largo plazo, edited by Paloma Fernández y Andrea Lluch, 71-94. España: Fundación BBVA.

Cerutti, Mario. 1992. Burguesía, capitales e industria en el Norte de México. Monterrey y su ámbito regional (1850-1910). México: Alianza Editorial/Universidad Autónoma de Nuevo León.

Cerutti, Mario, Isabel Ortega and Lylia Palacios. 2000. "Empresarios y empresas en el norte de México. Monterrey del Estado Oligárquico a la globalización.” European Review of Latin American and Caribbean Studies 69:3-27

Cerutti, Mario. 2006. Empresas y grupos empresariales en América Latina, España y Portugal. Monterrey: Universidad Autónoma de Nuevo León-Universidad de Alicante.

Cerutti Mario. 2007. "Los estudios empresariales en el norte de México (1994-2004).” In Los estudios de empresarios y empresas, Una perspectiva internacional edited by Jorge Basave and Marcela Hernández, 125-174. México: IIE c-UNAM/UAM-Iztapalapa/Plaza y Valdéz.

Cerutti, Mario. 2015. "Grandes empresas y familias empresariales en México." In Familias empresarias y grandes empresas familiares en América Latina y España: Una visión de largo plazo, edited by Paloma Fernández y Andrea Lluch, 153-187. España: Fundación BBVA.

Cerruti, Mario. 2005. "Redes y bolsones empresariales en el norte de México (1870-1920).” Paper presented at the VIII Congreso de la Asociación Española de Historia Económica, España, Universidad de Santiago de Compostela, September 13-16.

Cerutti, Mario and Carlos Marichal, eds. 1997. Historia de las grandes empresas en México. México: Fondo de Cultura Económica/Universidad Autónoma de Nuevo León.

Crespi, Gustavo and Pluvia Zuniga. 2012. "Innovation and Productivity: Evidence from Six Latin American Countries." World development 40(2):273-290. 
Chaston, Ian and Gregory J. Scott. 2012. "Entrepreneurship and open innovation in an emerging economy.” Management Decision 50(7):1161-1177.

Chaves Soto, Delfin and Jaime Páez. 1998. "Apertura, competitividad y estructura en empresas innovadoras en Colombia." Revista EAN 3334:91-90.

Dávila, Carlos, Joaquín Viloria, and Jorge Enrique Elías Caro. 2013. Los Estudios Empresariales en Colombia a Principios del Siglo XXI (Con una referencia a México). Colombia: Editorial Unimagdalena.

Del Giudice Manlio, Maria Rosaria Della Peruta, and Elias G. Carayannis. 2011. Knowledge and the Family Business The Governance and Management of Family Firms in the New Knowledge Economy. Australia: Springer.

Derossi, Flavia. 1977. El empresario mexicano. México: Instituto de Investigaciones Sociales-UNAM.

Erro, Carmen. 2003. Historia empresarial. Pasado, presente y retos de futuro. Barcelona: Ariel Empresa.

Fernández, Paloma. 2010. "The Study of family businesses from a global perspective - possibilities and limitations." Historia económica \& historia de empresas XIII 2:147-167.

Fernández, Paloma. 2012. La última globalización y el renacer de los grandes negocios familiares en el mundo. Bogotá: Universidad de los Andes-Facultad de Administración, Cátedra Corona 21.

Ferreira Lopes Santos, David, Leonardo Fernando Cruz Basso, Herbert Kimura and Eduardo Kazuo Kayo. 2014. "Innovation efforts and performances of Brazilian firms." Journal of Business Research 67(4):527-535.

Gamboa, Leticia. 1986. "Trayectoria de una familia empresarial de la industria textil de Puebla: Los Quijano-Rivero, 1864-1921." In Grupos económicos y organizaciones empresariales en México, edited by Julio Labastid, 57-81. Mexico: Biblioteca Iberoamericana-Alianza Editorial Mexicana-Instituto de Investigaciones Sociales de la Universidad Nacional Autónoma de México. 
Garay Tamajón, Luis and Xavier Font i Aulet. 2013. "Corporate social responsibility in tourism small and medium enterprises evidence from Europe and Latin America." Tourism Management Perspectives 7:38-46.

Gilbert, Jorge. 2009. "Redes sociales y vínculos familiares en los orígenes del grupo Tornquist." Anuario CEEED 1,1, Facultad de Ciencias Económicas, UBA: 43-72.

González Félix, Maricela. 2001. “Empresarios y Gobierno en el Distrito Norte, 1902-1920.” In Baja California. Un Presente con Historia, vol II edited by Catalina Velázquez, 13-28. México: Universidad Autónoma de Baja California.

Hougaz, Laura. 2015. Entrepreneurs in Family Business Dynasties Stories of Italian-Australian Family Businesses Over 100 Years. Australia: Springer.

Iacovone, Leonardo, Ferdinand Rauch, and L. Alan Winters. 2013. "Trade as an engine of creative destruction: Mexican experience with Chinese competition." Journal of International Economics 89(2):379-392.

Ibáñez, Francisco, Rafael Romero-Meza, Semei Coronado-Ramírez, and Francisco Venegas-Martínez. 2015. "Innovaciones financieras en América Latina: mercados de derivados y determinantes de la administración de riesgo.” MPRA Paper Num. 63151, posted 24.

Icazuriaga, Carmen. 1979. "El enclave sociocultural norteamericano y el papel de los empresarios en México." Centro de Investigaciones Superiores del INAH (Cuadernos de la Casa Chata) 35.

Jardon, Carlos M. and María Susana Martos. 2012. "Intellectual capital as competitive advantage in emerging clusters in Latin America." Journal of Intellectual Capital 13(4):462-481.

Kosacoff, Bernardo and Adrián Ramos. 2010. “Tres fases de la internacionalización de las empresas industriales argentinas. Una historia de pioneros, incursiones y fragilidad." Universia Business Review 25:56-75.

Lane, Suzanne, Joseph Astrachan, Andrew Keyt and Kristi McMillan. 2010. "Guidlines for Family Business Boards of Directors.” Family Business Review 23(2):155-169. 
Lansberg Ivan and Edith Perrow. 1991. "Understanding and working with Leading Family Business in Latin America." Family Business Review 4(2):127-147.

Lederman, Daniel, Julian Messina, Samuel Pienknagura, and Jamele Rigolini. 2014. Latin American Entrepreneurs: Many Firms but Little Innovation. The World Bank.

Lizama, Gladys. 2000. Zamora en el Porfiriato. Familias, fortunas y economía. México: El Colegio de Michoacán-H. Ayuntamiento de Zamora.

Lomnitz A. Larissa and Marisol Pérez Lizaur. 2001. "Redes sociales, cultura y poder. Ensayos de antropología Latinoamericana”. FLACSO de México-Miguel Ángel Porrúa.

Lomnitz A. Larissa and Marisol Pérez Lizaur. 1993. Una Familia de la Elite Mexicana, 1820-1980. Parentesco, clase y cultura. México: Alianza Editorial.

Lomnitz A. Larissa y Marisol Pérez Lizaur. 1979. "Los Gómez, una familia de empresarios de la ciudad de México." In Simposio sobre empresarios en México, edited by Pérez et al. Empresarios mexicanos y norteamericanos, y la penetración de capital extranjero (siglo XX), Centro de Investigaciones Superiores del Instituto Nacional de Antropología e Historia (Cuadernos de la Casa Chata), III, 23: 7-38.

Maquieira, Carlos P., Lorenzo A. Preve, and Virginia Sarria-Allende. 2013. "Theory and practice of corporate finance: Evidence and distinctive features in Latin America." Emerging Markets Review 13(2):118-148.

Marichal Carlos and Mario Cerutti. 1997. Historia de las grandes empresas en México (1870-1930). México: FCE.

McCarthy, Daniel J., Sheila M. Puffer, Denise R. Dunlap, Alfred M. Jaeger. 2012. “A Stakeholder Approach to the Ethicality of BRIC-firm Managers' Use of Favors." Journal of Business Ethics 109(1):27-38

Miller, Rory. 2010a. Foreign Firms and Business History in Latin America. Bogotá: Universidad de los Andes-Facultad de Administración, Cátedra Corona 18:90. 
Miller, Rory. 2010b. "Latin American Business History and Varieties of Capitalism.” Business History Review 84(4):637-674.

Morlán, Pablo. 2007. "Teoría e historia empresarial: un estado de la cuestión.” In Los estudios de empresarios y empresas, Una perspectiva internacional, edited by Jorge Basave and Marcela Hernández. México: IIE c-UNAM/UAM-Iztapalapa/Plaza y Valdéz.

Muntean, S. Clark. 2008. "Analyzing the Dearthin Family Enterprice Research.” In Theoretical Developments and Future Research in Family Business, edited by Phan and Buttler. Hong Kong: University of Hawai at Manoa.

Penfold, Michael, Andrés Oneto, and Guillermo Rodríguez Guzmán. 2015. "La transparencia del gobierno corporativo en las Empresas de Propiedad del Estado en América Latina.” Serie Políticas Públicas y Transformación Productiva, CEPAL, 20.

Peres, Willson, ed. 1998. Grandes empresas y grupos industriales latinoamericanos. México: Siglo XXI.

Poza, Ernesto. 1995. "Global Competition and the Family-Oened Business in Latin America." Family Business Review 8(4):301-211.

Quinones, Gerardo, Brian Nicholson and Richard Heeks. 2015. A Literature Review of EEntrepreneurship in Emerging Economies: Positioning Research on Latin American Digital Startups. Entrepreneurship in BRICS. Springer International Publishing: 179-208.

Roselia Servina, Roselia, Robert Lensinkb, and Marrit van den Berg. 2012. "Ownership and technical efficiency of microfinance institutions: Empirical evidence from Latin America." Journal of Banking \& Finance 36(7):2136-2144.

Staats, Joseph L. and Glen Biglaiser. 2012. "Foreign Direct Investment in Latin America: The Importance of Judicial Strength and Rule of Law.” International Studies Quarterly 56(1):193202. 
Szmrecsányi, Tamás and Ricardo Maranhao, eds. 1996. História de empresas e desenvolvimento económico. Asociación de Historia Brasileira de Pesquisadores em Historia Económica, Universidad de Sao Paulo.

Tapies, Josep, Elena San Román and Águeda Gil López. 2014. 100 familias empresariales que cambiaron el mundo. Las empresas familiares y la industrialización. Barcelona: Fundación Jesús Serra.

Tortolero, Alejandro. 1996. "Historia agraria y medio ambiente en México: estado de la cuestión." Noticiario de Historia Agraria 11:151-178.

Valerio, Sergio. 2002. "Empresarios extranjeros en Guadalajara durante el Porfiriato." Centro Universitario de Ciencias Sociales y Humanidades de la Universidad de Guadalajara (Colección: Producción Académica Miembros del SNI), México.

Vizcarra, Norma Leticia, Virginia Guadalupe López Torres and Imelda Yánez Ruiz. 2013. "Políticas públicas e incubadoras de empresas en México: un estudio longitudinal (1994-2013).” Revista Global de Negocios 3(3):55-66.

Von Mentz, Brígida, Verena Radka, Daniela Spenser and Ricardo Pérez Montfort. 1988. Los empresarios alemanes, el Tercer Reich y la Oposición de derecha a Cárdenas. Mexico: (I-II) Centro de Investigaciones y Estudios Superiores en Antropología Social-Ediciones la Casa Chata (Colección Miguel Othnón de Mendizábal), 11,12.

Wendlandt Amezaga, Teodoro R., Ángel Alberto. Amezaga, Ernesto A. Valdés Cuervo, Ernesto Alonso Carlos Martínez and Beatriz Ochoa Silva. 2015. “Grandes organizaciones empresariales en México y Chile: un análisis de perfiles con respecto a sus comunicaciones sobre responsabilidad social." Cuadernos de Administración (Universidad del Valle) 31(53).

This is an Open Access article distributed under the terms of the Creative Commons Attribution-Non-Commercial-No Derivatives License (http://creativecommons.org/licenses/by-nc-nd/4.0/), which permits non-comercial re-use and distribution, provided the original work is properly cited, and is not altered or transformed in any way. 